\title{
Teaching The Fundamentals of Civil EngineERING MATERIALS THROUGH EXPERIENTIAL LEARNING
}

\author{
Joshua Woods, Natalie Mazur, and John Gales* \\ Carleton University \\ *John.Gales@ carleton.ca
}

\begin{abstract}
This study presents an overview of a civil engineering materials course curriculum at Carleton University developed by the authors. The curriculum aims to move away from traditional civil engineering materials courses, which focus heavily on concepts related to material science, and instead concentrate on concepts that are more relevant to today's practicing civil engineers. The rationale, application, and analysis of the integration of these concepts through an advanced application of case-based and experiential learning is discussed. Central to this new course curriculum is a hands-on experiential learning activity on the construction and experimental testing of reinforced concrete beam specimens in lab sections of approximately 25 students. The goal of the lab is to provide students with a hands-on learning experience and use this as a tool to cover advanced topics related to civil engineering; for example, environmental sustainability and resilience. The assessment of the students' understanding of the concepts taught in class were performed through the use of an anonymous questionnaire distributed at the end of the course and through traditional examination and assignments. Results of the survey were compared between classes who engaged in the advanced experiential learning laboratory and those who did not. The results demonstrate that after introducing experiential learning into the course curriculum, students were more likely to form an educated opinion on the potential sustainability of a material. Experiential learning is shown to be a valuable tool for engineering education that, when used efficiently, can seamlessly incorporate newly emerging engineering concepts to ensure that graduating students are equipped with the knowledge and tools they require to be competitive in the job market. The relation of the course to contemporary accreditation of Graduate attributes is discussed at length along with critical information regarding the effectiveness of balancing student engagement in STEM subjects.
\end{abstract}

Keywords: experiential learning, civil engineering, materials, sustainability, resilience, stem, women, gender.

\section{INTRODUCTION}

In many undergraduate civil engineering curriculums, an introductory course in civil engineering materials is a student's first glimpse into their future careers as engineering professionals. It provides them with the fundamentals on how materials behave under different conditions, manufacturing processes, and applications to real-world engineering structures. However, more often than not, traditional courses on civil engineering materials have a heavy concentration on material science, which is rarely transferrable to a civil engineer's day-to-day activities. In addition, some civil engineering materials courses, including those offered at Carleton University, combine students from different civil-based engineering streams, including: Civil; Environmental; and Architectural Conservation Sustainability (ACS) engineers, into one classroom. Architecture students with no chemistry background also take these classes. This unique and complex diversity amongst students and the current demands from employers for young engineers well versed in advanced concepts, such as sustainability and resilience, led to the need to integrate these concepts into the civil engineering materials course curriculum. However, because these students are just beginning their engineering education, such advanced concepts can be difficult for students to conceptualize and potential applications to a real-world civil engineering problem are difficult to appreciate.

To overcome these challenges, examples of sustainability and resiliency amongst others are incorporated through a combination of teaching methods, namely, case-based and experiential learning ${ }^{1,2}$. In the newly implemented experiential learning activity, students are able to put advanced engineering concepts to the test in a hands-on laboratory environment and they are able to see with their own eyes the impact they have on the construction process and the structural performance of a material. The concepts utilized while conducting the labs are then reinforced and assessed during lecture, which provides additional case studies and/or applications of the concept to ensure the students fully realize their potential. 
This paper provides a detailed overview of the integrated civil engineering materials course curriculum as well as an in-depth study of the experiential learning activity. A sample course curriculum, timeline, and detailed experimental drawings are provided at the end of the paper for easy implementation/adaptation to other civil engineering programs at Canadian Universities (and abroad where applicable).

\section{BACKGROUND}

The civil engineering profession is a dynamic and rapidly evolving field in the $21^{\text {st }}$ century, which undergoes frequent advancements in the form of new materials, construction practices, technologies, and design philosophies. As a result, employers demand competent young engineering professionals who are well versed in the latest design fundamentals and strategies. Contrary to the engineering profession, the education of young engineers rarely undergoes dramatic changes and, in most cases, the material taught in basic undergraduate courses rarely changes. One could argue that the fundamentals of civil engineering never change and the material that forms the foundation of an engineer's knowledge is the same as it was some time ago. However, with newly emerging streams of engineering and advancement in the field, we must come to a realization that civil engineering course content should also be dynamic, focusing on new and innovative concepts to ensure graduating engineers have the tools they need to succeed in the workplace. The lack of modernization in engineering course curriculums has resulted in a divide between the demands of the engineering company and the skills possessed by graduating engineers.

One such example is a second year course in civil engineering materials. From afar, this course provides an ideal opportunity to introduce newly emerging materials and design philosophies into the mind of young professionals early on in their degree. However, in most cases, these courses remain trapped in the past, focusing on material that is either out-of-date with current engineering material, so is of no practical use to an engineer, and/or, in a broad sense, out-of-date teaching practices that negate the modern diversity in our university classes. For example, the civil engineering materials course offered at Carleton University has remained relatively unchanged over the past 15 years. A quote below, taken from the course outline, showcases the intended learning objectives of the course: "Introduce students to material science including the structure of atoms, crystallography and crystal imperfections and; discuss the characteristics, behaviour and use of Civil Engineering materials including steel, concrete, asphalt, wood, polymers and composites their specifications, physical, chemical, thermal and mechanical properties.
The students will also learn about fatigue and corrosion of metals." Although the course focuses on the core materials that are essential in an engineering education, the first half of the course originally involved topics that are heavily related to material science. This material is of very little use in the day-to-day activities of a practicing civil engineer. It is important to realize that in these situations, the course should accommodate the specific needs of these students, and ensure that the material that is covered is equally relevant to any other fields of engineering. Appendix A, located at the end of the paper, summarizes the basics of the civil engineering materials course curriculum employed in the past at Carleton University (between 2000 and 2014). An analysis of the course topics demonstrates that they speak very little to newly emerging technologies and materials such as polymers and engineered timber. That course curriculum lacks connections between engineering materials and design methodologies such as sustainability, heritage conservation, and resiliency. In addition, the experiential learning activities present in the old curriculum include traditional steel coupon testing, residual strain measurement, stub column testing, and concrete mix design/cylinder testing. Although these labs can be effective for demonstrating the basic properties of civil engineering materials, they do not necessarily provide an opportunity for hands-on learning, higher level thinking, or introduce any of the previously discussed emerging topics in civil engineering. They risk meeting more stringent accreditation graduate attributes.

\section{CIVIL ENGINEERING MATERIALS UNDERGRADUATE CLASS}

\subsection{Course Curriculum}

Because of the demand from employers for young engineering professionals well versed in newly emerging technologies and design concepts, as well as demand from students for material relevant to their future careers, a new civil engineering materials course curriculum has been developed and implemented at Carleton University. The course is divided into seven core modules, each focusing on a material relevant to civil engineering practices. Appendix A provides an in-depth overview of the adopted curriculum. The seven core modules include the basics in material science, steel, concrete, timber, soil, transportation engineering materials, and polymers. In comparison to the curriculum employed in previous years, the shift from a heavy emphasis on material science towards the practical applications of engineering materials is evident. Although the students are still taught the basics in material science, it does not extend past what will be required of a conventional practicing civil engineer (the 
lecturer actively works with two reputable multi-national engineering design firms which provoked this course overhaul). The course topics provide a much broader focus on the manufacturing, material properties, material types, testing techniques, and suitability of different materials for specific applications. In addition to the seven core modules, there are four sub-modules that focus on key concepts relevant to civil-based engineering streams, including material degradation, iconic construction, sustainable construction, and resiliency. The addition of these submodules allows the course to focus on concepts that might be more relevant/interesting to all civil-based engineering streams enrolled in the course (e.g. environmental, architectural conservation and sustainability, etc. - to be discussed in later portions of this paper), but still remains very relevant to those with a civil concentration.

To expose the students to real-world engineering applications of the materials and design concepts they are taught through traditional lecture, field trips and several case studies that are incorporated into the course curriculum. These case studies provide an opportunity for in-depth examination of a real-world engineering problem, focusing on a particular topic covered in the course. Some concepts that have been incorporated into the case studies include: the role that material failures have on civil engineering disasters, heritage structures, the connections between architecture and engineering, and sustainable redevelopment. Table 1 lists the major case studies discussed during the most recent offering of civil engineering materials at Carleton University. The use of a case-based teaching strategy allows advanced concepts such as sustainability and resiliency to be actively incorporated into the course. For example, the concept of sustainability, which had been discussed in lecture, was integrated into the course content through the discussion of the Corktown Commons sustainable redevelopment project in Toronto. A site contaminated with industrial waste because of its previous use as a site for manufacturing, Corktown Commons underwent a sustainable redevelopment to decontaminate the land and transform it into usable space for the 2015 Pan-American games. The case covers topics relevant to environmental engineers in the form of site decontamination (brownfield), architectural conservation by focusing on the heritage aspects of the site, and civil engineers in the sustainable design of new multi-use structures on the site.

The experiential style of learning is also easily adaptable to new topics, as lecturers are able to introduce new concepts as sub-modules and can select cases to cover in class that complement the concept.

To ensure core components are taught effectively, case studies similar to those presented in class are used in $75 \%$ of the exam problems. The first assignment uses traditional problems, and the second course assignment uses comprehensive problems related to case studies. All problems are explicitly targeted towards meeting the Graduate attributes (see Section 3.5). The bulk of the second assignment has the students research their own case study on the theme of sustainability.

Table 1. Civil Engineering Materials Case Studies.

\begin{tabular}{|c|c|c|}
\hline Case & Description & Concept \\
\hline $\begin{array}{l}\text { Real } \\
\text { Buildings } \\
\text { and } \\
\text { Failures }\end{array}$ & $\begin{array}{l}\text { Quebec Bridge (1907); Silver } \\
\text { Bridge (1967); Heron Road } \\
\text { Bridge (1966); Hyatt Regency } \\
\text { (1981), Elliot Lake (2012) }\end{array}$ & $\begin{array}{l}\text { Material } \\
\text { failures, } \\
\text { Corrosion, and } \\
\text { Resiliency }\end{array}$ \\
\hline $\begin{array}{l}\text { Prestressing } \\
\text { Steel in Fire }\end{array}$ & $\begin{array}{l}\text { High temperature response of } \\
\text { prestressing steel }\end{array}$ & $\begin{array}{l}\text { Stress- Strain, } \\
\text { Instruments }\end{array}$ \\
\hline $\begin{array}{l}\text { RCA in } \\
\text { Real } \\
\text { Buildings }\end{array}$ & $\begin{array}{l}\text { Use of recycled concrete } \\
\text { aggregate }(R C A) \text { in real } \\
\text { structures around the world }\end{array}$ & $\begin{array}{l}\text { Sustainable } \\
\text { Materials }\end{array}$ \\
\hline $\begin{array}{l}\text { Jeddah } \\
\text { Tower, } \\
\text { Brazil } \\
\text { Museum }\end{array}$ & $\begin{array}{l}\text { Use of high performance } \\
\text { concrete and self- } \\
\text { consolidating concrete } \\
\text { around the world }\end{array}$ & Resiliency \\
\hline $\begin{array}{l}\text { Carlton } \\
\text { Tavern }\end{array}$ & $\begin{array}{l}\text { Unlawful demolition of a } \\
\text { heritage structure led to } \\
\text { demands to rebuild it in } \\
\text { original condition }\end{array}$ & $\begin{array}{l}\text { Heritage } \\
\text { Structures }\end{array}$ \\
\hline $\begin{array}{l}\text { Concorde } \\
\text { Overpass }\end{array}$ & $\begin{array}{l}\text { Collapse of the Concorde } \\
\text { overpass because of freeze- } \\
\text { thaw cycles }\end{array}$ & $\begin{array}{l}\text { Material } \\
\text { Degradation }\end{array}$ \\
\hline $\begin{array}{l}\text { Wayne } \\
\text { Gretzky } \\
\text { Centre }\end{array}$ & $\begin{array}{l}\text { Recreation complex utilizing } \\
\text { engineered timber products; a } \\
\text { sustainable alternative }\end{array}$ & $\begin{array}{l}\text { Sustainable } \\
\text { Construction }\end{array}$ \\
\hline $\begin{array}{l}\text { London } \\
\text { Financial } \\
\text { District, } \\
\text { World } \\
\text { Libraries }\end{array}$ & $\begin{array}{l}\text { Application of building } \\
\text { materials to many iconic } \\
\text { building structures }\end{array}$ & $\begin{array}{l}\text { Architecture } \\
\text { and } \\
\text { Engineering }\end{array}$ \\
\hline $\begin{array}{l}\text { Harriet } \\
\text { Rees House }\end{array}$ & $\begin{array}{l}\text { Move of a historic site and } \\
\text { the challenges with the } \\
\text { transportation of a structure }\end{array}$ & $\begin{array}{l}\text { Heritage } \\
\text { Structures }\end{array}$ \\
\hline $\begin{array}{l}\text { Bridge } \\
\text { Culvert }\end{array}$ & $\begin{array}{l}\text { Study of Leda clay, } \\
\text { Champlain Sea Clay, Billings } \\
\text { shale and its unique material } \\
\text { characteristics and hazards }\end{array}$ & Local Materials \\
\hline $\begin{array}{l}\text { Corktown } \\
\text { Common }\end{array}$ & $\begin{array}{l}\text { Industrial waste site rehab } \\
\text { into a mixed-use site }\end{array}$ & $\begin{array}{l}\text { Sustainable } \\
\text { Construction }\end{array}$ \\
\hline $\begin{array}{l}\text { Eight } \\
\text { Avenue } \\
\text { Place }\end{array}$ & $\begin{array}{l}\text { A high-rise building in } \\
\text { Calgary designed to meet } \\
\text { LEED gold standards }\end{array}$ & $\begin{array}{l}\text { Sustainable } \\
\text { Construction }\end{array}$ \\
\hline $\begin{array}{l}\text { Kettle } \\
\text { Creek } \\
\text { Bridge }\end{array}$ & $\begin{array}{l}\text { Conversion of a historical } \\
\text { civil engineering structure } \\
\text { into an elevated urban park }\end{array}$ & $\begin{array}{l}\text { Resiliency/Cond } \\
\text { ition Assessment }\end{array}$ \\
\hline $\begin{array}{l}\text { Self- } \\
\text { Healing } \\
\text { Concrete }\end{array}$ & $\begin{array}{l}\text { An innovative material that } \\
\text { uses bacteria to seal cracks, } \\
\text { improving concrete life-span }\end{array}$ & Resiliency \\
\hline
\end{tabular}


In past years, the students were required to purchase a course textbook on Materials for Civil and Construction Engineers by Mamlouk ( $\$ 200$ for a net publisher sales of $\$ 44,000$ assuming all students purchase). However, given the shift towards introducing innovative concepts related to civil engineering and real-world case studies from relevant civil engineering publications, the course notes, which included many references to other publications for additional in-depth information, proved sufficient. Using this model, new cases can be easily introduced each year to provide a fresh perspective on the concept (alleviating the problem of students copying previous year assignments). Excellent sources for case studies relevant to newly emerging technologies and with connections to industry are magazines such as ARUP Journal, ASCE Civil Engineering Journal, Concrete International magazine, Modern Steel Construction magazine, as well as their Canadian counterparts Advantage Steel, for example. Professors or departments often hold subscriptions to these publications, such that they can be made easily available to students and faculty alike. The students are asked to read a book titled "After the flood" by A. Hay ( $\$ 45$ on Amazon), which is based on the concepts of community resiliency, and chronicles a young woman engineer and her experiences working in the city of Toronto. The book is also utilized at the University of Toronto to teach these concepts. This approach to teaching allows professors to choose and interchange cases that they feel might have the greatest impact on their current students, such as those which are close geographically or a project that is popular in the news/social media. These subtleties can spike student engagement and help reinforce the topics covered in lecture.

\subsection{Experiential Learning Activities}

To strengthen and build upon the concepts introduced in the course lectures and cases presented in class, an innovative experiential learning activity was introduced in 2016. Although experiential learning is certainly not a new concept, an advanced application of experiential learning was utilized in this course as a tool to demonstrate complicated engineering concepts that would not have otherwise been possible to showcase, such as sustainability and resiliency. The experiential learning activity incorporated into the civil engineering material curriculum included the construction and experimental testing of reinforced concrete beam specimens in lab sections of approximately 25 students. Appendix B shows the geometry, reinforcement details, average material properties, and failure loads for the beam specimens tested. Each lab section was responsible for the construction and testing of three reinforced concrete beams: one without any steel reinforcement (plain concrete), one with only flexural (longitudinal) reinforcement, and one with flexural and shear (transverse) reinforcement. In addition, each section was responsible for casting four cylinders to measure the compressive and tensile strengths of the concrete and conducting a slump test on the fresh concrete.

This laboratory builds on the traditional concrete casting/cylinder testing that is present in most civil engineering materials courses and takes it one step further, providing students with an opportunity to see first-hand the work that goes into the construction of a basic structural element. It also allows them to see the influence of engineering design in the form of concrete materials, mix design, and rebar placement, on the mechanical performance of a structural element. Figure 1 shows the three failure modes for each of the beam specimens. Although the students were not able to fully appreciate the influence of reinforced concrete design on each of the three failure modes, having not taken an introductory course in concrete design, they were still able to appreciate the benefits of the different design parameters and their impact on basic structural performance parameters, such as maximum strength, deflection, and concrete crack patterns. Exposing the students to the construction and design processes and the impact these have on potential failure modes earlier on in their degree will also facilitate familiarity with the subject matter, leading to quicker learning during advanced third and fourth year courses in structural design. This also helps the second year students compete with more senior students for employment, as they have been exposed to design principles in the second year of their degree. To assess comprehension, the students submit a group report and complete exam questions $(20 \%$ of the exam being based on their experiences).

Although students are typically exposed to small scale material tests in a civil engineering materials course, the experiential learning activities allow students to appreciate the difficulties of large-scale testing, and they showcase typically employed instrumentation. Instrumentation utilized during the experiments included displacement transducers (Fig. 1), traditional strain gauges, and a newly emerging measurement technology, digital image correlation, which uses high-definition photographs to track strain and displacement over the surface of an element (used at Cambridge, Imperial College, Queen's Canada etc.). Explaining such technology could be difficult during a classroom environment, however, after seeing the technology employed first-hand and its results, students have a better appreciation for how it works and what the technology can do. As technology evolves and better or advanced instrumentation is available, it can also be seamlessly incorporated into the laboratory. 


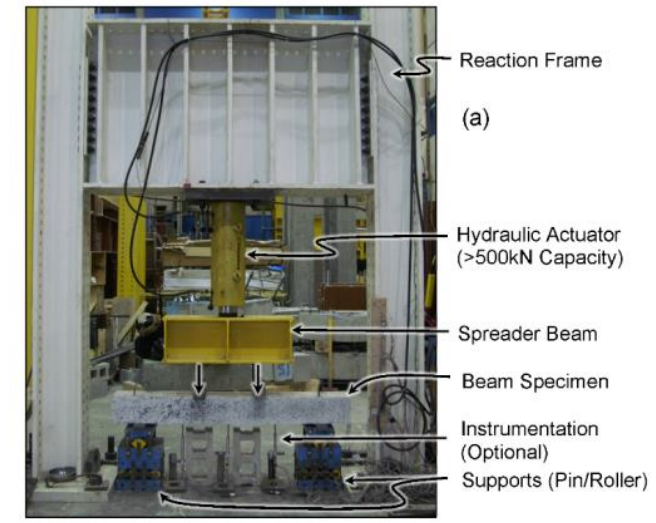

(b)

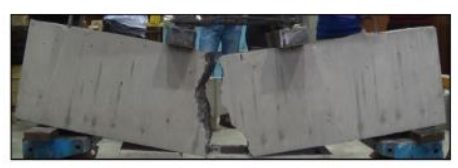

(c)

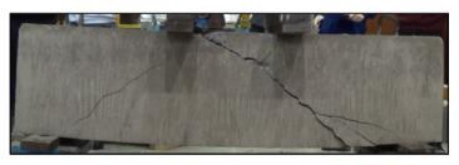

(d)

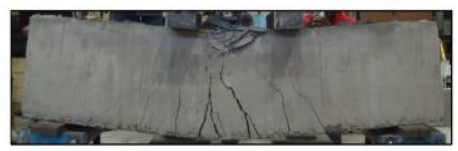

Fig. 1. (a) Test setup; Failure modes: (b) cracking moment; (c) shear failure; (d) flexural failure.

To introduce newly emerging concepts in the field of civil engineering, such as sustainability and resiliency, to the experiential learning activity, innovative materials were used to construct some of the beam specimens. The concept of sustainability was introduced through the use of recycled concrete aggregates (RCA), an environmentally friendly alternative to traditional concrete aggregate used as a replacement for some or all of the conventional aggregate in the beam specimens. RCA is crushed and graded structural concrete normally used for construction and demolition waste. Using different materials allowed students not only to compare the physical properties of the materials (look and feel) but also to assess the impact they had on workability of the concrete and its structural performance compared to conventional materials. Furthermore, the concept of resilience was also incorporated through the use of fiberreinforced polymers (FRP) sheets. The FRP material was applied to some of the beam specimens to demonstrate that a structure can be capable of resisting imposed loads with a lower level of damage, thus being more resilient. The application of FRP in structural repair and retrofit contexts can also be emphasized and linked back to case studies covered in lecture. By performing laboratories, students were given an opportunity to reflect on the material taught in lecture and view these concepts first hand.

Students are also taken on field trips during the tutorial time. In 2016, the students were taken to a quarry pit where they saw asphalt and aggregate production. At the quarry, the production of recycled concrete was highlighted. In 2016, as part of the Material Science module, the students were taken to a deteriorating bridge where the lecturer demonstrated and explained a carbonation test (using a phenolphthalein solution of chipped concrete) to illustrate the effects of corrosion on structures (Fig. 2). Good concrete is a 'base'; where concrete exposed to $\mathrm{CO}_{2}$ (as in bridge structures) will form a more 'acidic' surface. This will promote corrosion. A 'pink' result after application of phenolphthalein indicates that the concrete is a basic environment; no pink indicates a more acidic concrete which is susceptible to corrosion of embedded steel. The phenolphthalein is a weak acid, and can react with a basic concrete to leave behind pink particles from its otherwise clear solution. An acidic surface will not visibly react with the weak acid and will merely have a pool of clear liquid remain.

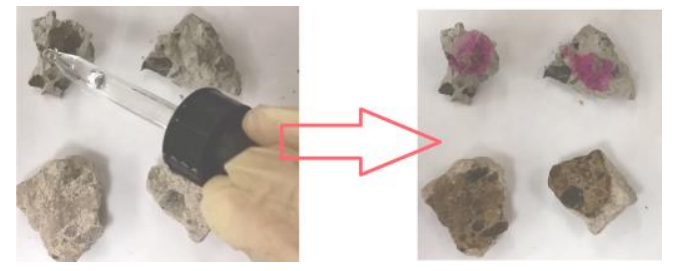

Fig. 2. A carbonation test is performed with the students to illustrate material chemistry.

The innovation in these types of in-depth experiential learning activities comes in their ability to seamlessly incorporate any number of newly emerging or utilized technologies into the laboratory and classroom through experimental testing. This allows the students to be exposed to advanced topics in engineering earlier and help them to understand the material faster than using a conventional lecture-style approach.

\subsection{Survey and Results}

Beyond traditional exam, to assess the students' understanding of the concepts discussed in the course and their opinions on the newly developed experiential learning activity, an anonymous and optional questionnaire was distributed at the end of the course.

Table 2 shows the survey questions distributed in two classes in two different years: one in which the students were exposed to a traditional curriculum and one in which the students were exposed to the modified case-based and experiential learning curriculum. The overall response rate for both classes was greater than $85 \%$. 
Table 2. Survey Questions.

\begin{tabular}{c|l}
\hline & \multicolumn{1}{|c}{ Question } \\
\hline A & What was your favorite case study covered? (2016 only) \\
\hline B & $\begin{array}{l}\text { What did you like about the concrete lab session you } \\
\text { were in? }\end{array}$ \\
\hline $\mathrm{C}$ & $\begin{array}{l}\text { What did you dislike about the concrete lab session you } \\
\text { were in? }\end{array}$ \\
\hline $\mathrm{D}$ & $\begin{array}{l}\text { What do you think needs improving about the concrete } \\
\text { lab session you were in? }\end{array}$ \\
\hline $\mathrm{E}$ & $\begin{array}{l}\text { Can concrete be sustainable? } \\
\text { (You may wish to include your opinion to what } \\
\text { sustainability means) }\end{array}$ \\
\hline
\end{tabular}

In response to Question $\mathrm{A}, 75 \%$ of students in the modified curriculum identified one (or more) case studies discussed throughout the course of the term. This suggests that the case studies presented had a lasting impact in the minds of the students and can be used as an effective tool to facilitate connections between concepts taught throughout the course and real-world engineering applications. In addition, the familiarity with real-world engineering projects and its value to future employers should not be overlooked. It should be noted that lecture notes are made available to the students through a 'moodle' device (a moodle device is an online course website), though the notes do not typically contain the case studies.

Students were also asked their opinions (positive and negative) on the experiential learning technique and how to improve the curriculum for future years through the same survey. The overwhelming negative from students in 2016 in response to questions B and C was the size of the lab groups. Approximately $80 \%$ of students felt that there were too many students in their tutorial section for them to fully appreciate the material/concepts being presented or to actively participate in all aspects of the activity. Although class size is more often than not outside of the instructor's control, the overwhelming response does emphasize the importance of small class sizes, particularly in teaching styles where student engagement benefits from active participation.

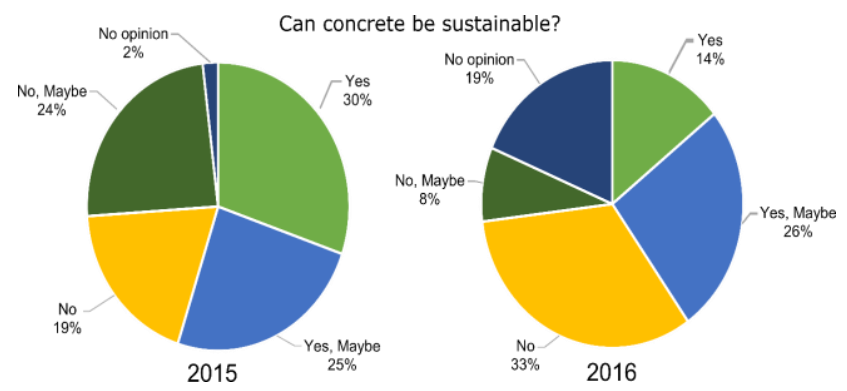

Fig. 3. Survey results for question $\mathrm{E}$.
Figure 3 shows a comparison between a class who learned about sustainability through experiential learning in 2016, and one who learned about sustainability through a more traditional lecture style only in 2015 . The results from Question E demonstrate that after introducing experiential learning into the course curriculum, students are more likely form an educated opinion on the potential sustainability of a material. In 2015, 59\% of students said concrete could 'maybe' be sustainable, while in 2016 only $34 \%$ of students indicated 'maybe'. In addition, $40 \%$ of students in 2016 offered a written definition as to what their opinion of sustainability was, while in 2015 only $10 \%$ of students provided a written definition.

\subsection{Student Engagement}

The course has had very good student satisfaction with implementation of these changes. Attendance is periodically recorded through submission of opinion based responses during the course of the year. Regularly the attendance was only as low as $73 \%(n=222)$. The course evaluation was a score of $4.88 / 5.00$ while faculty norms were 4.29/5.00. Two teaching assistants were awarded with TA of the year for Civil and Environmental Engineering respectively and the lead instructor, the corresponding author, was awarded Best Professor by the Carleton Student Engineering Society, and invited to guest speak at student seminars with Green Builders and Engineers without Borders, student groups heavily involved in Sustainability initiatives.

Women have done particularly well in the course, consistently achieving at the top of the class, despite making up only $25 \%$ of the students. The low female to male enrollment ratio in the course reflects a serious challenge seen in the fields of science, technology, engineering, and mathematics (STEM fields) globally; namely, the underrepresentation of women. Recruitment and retention of women in STEM fields are significantly poorer than in other fields, and have been stagnant for years $3,4,5$. Women represent half of the population, but they are underrepresented. Their knowledge and unique perspectives conducive to innovation is not balanced with that of men's. The curriculum discussed in this paper clearly engaged the women in the course, as evident from their exceptional achievement and positive feedback. Some aspects of this curriculum are very easy to implement in the classroom, and beneficial to all students.

The course curriculum focuses on building practical skills, in addition to teaching traditional theory, in order to enable students to be more competitive in the job market. Showing how what they learn is directly transferable to their future career is useful to every student, and is especially important for female students, motivating them to continue their studies in the discipline. The more 
women that pursue STEM careers, the more exemplars there will be to encourage women to consider further education in STEM fields. Higher rates of retention can feed back to build a balanced and diverse field. It must be recognized that retention be considered beyond merely graduation.

Additionally, the modified curriculum, which incorporate experiential learning, emphasizes working in groups and engaging with the professor and peers during experiential activities. This fosters a collaborative atmosphere more conducive to learning than independent work in a traditional curriculum. For women especially, an open and equal opportunity to interact with peers and reflect on course material prepares students to be assertive as well as to be effective problem solvers.

Giving students in all minorities a chance to actively participate relieves some anxiety they may have about not being heard, and allows these students time to focus on learning the material.

Although the curriculum itself can help engage and sustain women in STEM subjects, the role of the instructor in fostering student achievement is equally important to consider. The professor teaching the course at Carleton University had an open-door policy, where students were encouraged to ask for help when they needed it. Flexibility in availability takes up more of a professor's time than set office hours would, but it can also help avoid grade disputes and problems at the end of the term. Time put into helping students understand the material is more constructive than time put into resolving complaints and issues. In previous years, the students who went to the professor's office for help outside the classroom did better in the course. Each student that visited the office, for final exam review, was asked if their student number could be recorded for statistical purposes. The final grades of those who stopped by the office were significantly higher $(\mathrm{M}=84 \%)$ than those who did not attend $(M=71 \%)$. Women especially benefitted from the open office policy; $50 \%$ of women enrolled in the course took advantage of the open office schedule, while only $21 \%$ of men did. The ratio of men to women attending the open office hours was roughly $1: 1$, a stark contrast to the ratio of men to women enrolled in the course, which was roughly $3: 1$. Having the office door open, an inviting office environment, and being genuinely interested in helping a student, male or female, create a positive and welcoming atmosphere ideal for learning. For women especially, knowing that they are welcome when they are a minority amongst their peers promotes their selfconfidence and encourages their participation in the course, and, more broadly, the STEM fields.

Teaching Assistants can further ensure that the students in their course have the confidence and resources to involve themselves in the class. Often, an instructor can seem far removed from the students or may not be available to help too many students at once. Teaching assistants are a valuable support system that students can trust with some of their general questions and concerns. Therefore, the way the teaching assistants engage with the students is as important as the way the instructor does. Appropriate training for teaching assistants in university regulations is essential. They must be able to manage a wide variety of diverse students. Having teaching assistants use the same strategies as the instructor uses for encouraging women to participate can not only ensure consistency in the teaching method, but it also reinforces a welcoming atmosphere for the students.

Engaging with all students equally, male and female, can help women achieve their potential. Making eye contact with female and male students equally, encouraging students other than regular participators to speak, and acknowledging the comments and opinions of each student are key strategies for promoting the increased engagement of women. The classroom should be an environment that promotes participation and critical thinking. By acknowledging the equal importance of minorities in the class and everyone else, students who may already feel out of place by being in the minority can gain the confidence to engage with their peers on equal grounds. This stimulates more productive discussion both in the short term and in the long term, as it adds perspectives that might have otherwise been left out. Everyone benefits from being heard and more informed.

\subsection{Graduate Attributes}

The renewed course delivers on Impact of engineering on society and the environment by focusing on "The place of engineering in society"; "Sustainable design, life-cycle planning"; and "Health, safety and risk". To do this the course utilizes its assignment based questions to have the students research their own case study building. Furthermore, by dealing explicitly with corrosion within the assignment in a practical based question, the students are placed in the role of the engineer and are asked to find and document evidence of deteriorating concrete within the community. The experiential learning mentioned in preceding sections introduces students to attributes from design, investigation, problem analysis and group work, all in second year. By still dealing with the main elements, as they are traditionally, there is no impact on the course's previous accreditation. The curriculum merely adds to the fundamental engineering concepts that were there before.

\section{PRELIMINARY CONCLUSIONS}

This paper presents a broad overview of a newly implemented civil engineering materials course curriculum at Carleton University. The course is designed 
around the concepts of case-based and experiential learning. Many civil engineering materials courses offered at Canadian Universities in the past, including at Carleton, have devoted a large portion of the course material to concepts related to material science. Although relevant for engineers who aspire to work with a primary focus on material development, the fact is that this detailed level of knowledge related to material science is not required by the majority of practicing civil engineers on a day-to-day basis. On top of that, many civil engineering materials course offerings have more than one stream of engineering students taking the course, for which topics related to material science are even less practical. The newly developed course curriculum focuses on concepts that are more relevant in today's engineering practice, including but not limited to sustainability, heritage conservation, and resiliency. Students are exposed to a number of engineering case studies, which demonstrate how the concepts taught in class can be applied to a real-world engineering problem. In addition, a comprehensive experiential learning activity, which included construction and testing of several large reinforced concrete beam specimens proved to be an ideal activity to present more advanced topics to the students faster. Survey results conducted on two classes suggest that the reimagined course curriculum improves student retention of advanced engineering concepts. In today's workplace, there are significant demands from employers for young engineers, of all backgrounds, well versed in advanced concepts such as sustainability and resilience. Through the introduction of advanced concepts earlier on in their degree, the goal is that this will ensure that graduating students are equipped with the knowledge and tools they require to be competitive in the job market.

\section{FUTURE WORK}

Although this paper provides a broad overview of the currently employed curriculum used to teach Civil Engineering materials at Carleton University, it is easily observed that this curriculum is intended to be dynamic in nature, such that it evolves with advancement in newly emerging civil engineering technologies and design methodologies. However, some future directions of the course will include expanding the beam testing experiential learning activity to include beams of different materials, such as steel and engineered timber (glulam/LVL/LSL), to expose students to the structural performance and failure modes of different civil engineering materials. In the upcoming cohort of civil engineering materials, tutorial sections typically related to problem solving will be replaced with visits to local bridges and construction sites. Bridges within walking distance provide an excellent opportunity to showcase different construction materials, including concrete, steel, and polymers. In addition, they also typically showcase concepts related to material degradation including concrete spalling/cracking/staining and corrosion to steel reinforcement. Construction sites can provide a valuable opportunity for students to see how materials are handled and installed on-site and the challenges associated with the construction of civil engineering structures.

\section{Acknowledgements}

The authors would like to thank Ben Nicoletta, for his dedication in the design and construction of the beam specimens. The Natural Science and Engineering Research Council (NSERC) of Canada is acknowledged for helping support the research studies of Joshua Woods. Material donations of the CFRP materials from Sika Canada are also gratefully acknowledged.

\section{References}

[1] Gales, J., Folk, L., and Gaudreault, C. (2016) The Study of Human Behavior in Fire Safety Engineering using Experiential Learning. 7th Canadian Engineering Education Association's Annual Conference., Halifax, Canada 8 pages.

[2] Kolb, D.A. Experiential learning. Englewood Cliffs, NJ: Prentice Hall. 1984.

[3] Hill, C., Corbett, C., and St. Rose, A. (2010) Why So Few? Women in Science, Technology, Engineering, and Mathematics. Washington, DC: American Association of University Women

[4] Milgram, D. (2011) How to Recruit Women and Girls to the Science, Technology, Engineering, and Math (STEM) Classroom, Technology and Engineering Teacher 71(3), 411

[5] Diekman, A.B., Weisgram, E.S., and Belanger, A.L. (2015) New Routes to Recruiting and Retaining Women in STEM: Policy Implications of a Communal Goal Congruity Perspective, Social Issues and Policy Review 9(1), 52-88 


\section{APPENDIX A: \\ Comparison of Civil Engineering Materials Course Curriculums}

Table A1. Traditional Civil Engineering Materials Curriculum.

\begin{tabular}{|c|c|}
\hline Course Topics & Topics Descriptions \\
\hline $\begin{array}{l}\text { Intro to } \\
\text { material science }\end{array}$ & $\begin{array}{l}\text { Classification of materials; mechanical } \\
\text { properties of engineering materials; Selection } \\
\text { Criteria }\end{array}$ \\
\hline $\begin{array}{l}\text { Structure of } \\
\text { atom and } \\
\text { atomic bonding } \\
\end{array}$ & $\begin{array}{l}\text { Structure of atom; types of bonding; bond } \\
\text { energies; properties of solids }\end{array}$ \\
\hline $\begin{array}{l}\text { Structure of } \\
\text { crystalline } \\
\text { solids }\end{array}$ & $\begin{array}{l}\text { Metallic crystal structure; co-ordination number } \\
\text { of atom packing factor; polymorphism and } \\
\text { allotropy; }\end{array}$ \\
\hline $\begin{array}{l}\text { Development } \\
\text { microstructure }\end{array}$ & $\begin{array}{l}\text { Solidification; crystallization; phase change; } \\
\text { phase diagram; microstructure (porosity, grain } \\
\text { size) }\end{array}$ \\
\hline $\begin{array}{l}\text { Surface } \\
\text { properties }\end{array}$ & $\begin{array}{l}\text { Surface energy and surface tension; interfaces; } \\
\text { wetting; absorption; surfactants; adhesion; }\end{array}$ \\
\hline Steel & $\begin{array}{l}\text { Structure and composition; production; } \\
\text { classification and properties; elastic and plastic } \\
\text { behaviour }\end{array}$ \\
\hline Steel Corrosion & $\begin{array}{l}\text { Electrochemical considerations; corrosion; } \\
\text { passivity; environmental effects; corrosion } \\
\text { prevention }\end{array}$ \\
\hline Concrete & $\begin{array}{l}\text { Constituent materials; sitting and hydration; } \\
\text { properties; concrete mix design }\end{array}$ \\
\hline Asphalt Mixes & Types of asphalt; properties; grades \\
\hline Woods & $\begin{array}{l}\text { structure and properties; shrinkage and } \\
\text { seasoning; treatment and durability; mechanical } \\
\text { properties; products }\end{array}$ \\
\hline $\begin{array}{l}\text { Advanced } \\
\text { Polymers }\end{array}$ & $\begin{array}{l}\text { applications; reinforcement types; matrix } \\
\text { materials; products }\end{array}$ \\
\hline
\end{tabular}

Table A2. 2016-17 Civil Engineering Materials Curriculum.

\begin{tabular}{|c|c|}
\hline Course Module & Topics and Descriptions \\
\hline $\begin{array}{l}\text { Material } \\
\text { Science }\end{array}$ & $\begin{array}{l}\text { Why study materials?; Material Science: } \\
\text { microstructures; types; properties; measuring } \\
\text { properties; Instrumentation } \\
2 x 1.5 \text { hr Lecture } \\
\end{array}$ \\
\hline Steel & $\begin{array}{l}\text { Steel and Alloys: classification; phase diagrams; } \\
\text { annealing; hardening and quenching; tempering; } \\
\text { history; high strength steel; Manufacturing: } \\
\text { mining; slag; furnace types; cold-formed steel } \\
\text { Aluminum: properties; uses; production; forming; } \\
\text { designation Evaluation: tensile test; flexural test; } \\
\text { torsion test; hardness test } \\
2 x 1.5 \text { hr Lecture }\end{array}$ \\
\hline Cementitious & $\begin{array}{l}\text { Aggregates: source; classification; properties } \\
\text { Portland cement: manufacturing; hydration; } \\
\text { types; properties Admixtures: types (air- } \\
\text { entrainers, water reducers); mix design Concrete: } \\
\text { High-performance concrete (HPC); Self- } \\
\text { consolidating concrete (SCC); Shotcrete; curing; } \\
\text { properties; destructive and non-destructive testing } \\
\text { Masonry; classification; manufacturing; mortar } \\
5 x 1.5 \text { hr Lecture }\end{array}$ \\
\hline $\begin{array}{c}\text { Material } \\
\text { Degradation }\end{array}$ & $\begin{array}{l}\text { Degradation: physical/chemical; concrete } \\
\text { durability; corrosion } \\
1 \text { x1.5hr Lecture }\end{array}$ \\
\hline $\begin{array}{c}\text { Iconic } \\
\text { Construction }\end{array}$ & $\begin{array}{l}\text { Architecture and engineering } \\
1 \times 1.5 \mathrm{hr} \text { Lecture }\end{array}$ \\
\hline Timber & $\begin{array}{l}\text { Wood: classification; species; macro and micro } \\
\text { structure; moisture; seasoning; shrinkage; } \\
\text { treatment; properties; grading; Engineered } \\
\text { timber: glulam; cross-laminated timber; plywood; } \\
\text { OSW; LVL; PSL; pre-fabricated joists } \\
2 x 1.5 \mathrm{hr} \text { Lecture; Guest lecture }\end{array}$ \\
\hline Soil & $\begin{array}{l}\text { Description; properties; Leda clay; slope stability; } \\
\text { foundations; grain size curves; soil classification; } \\
\text { specific gravity } \\
1 \text { x1.5hr Lecture } \\
\end{array}$ \\
\hline Transportation & $\begin{array}{l}\text { Asphalt cement/concrete; layers; production; } \\
\text { maintenance; fog seal; crack sealing; rutting; } \\
\text { thermal cracking; mix design } \\
1 \times 1.5 \text { hr Lecture }\end{array}$ \\
\hline Polymers & $\begin{array}{l}\text { Polymers: types; applications; molecular } \\
\text { structure; mechanical behaviour; stress } \\
\text { relaxation; recycling; plastic/composite lumber } \\
\text { Composite polymers: advantages; classification; } \\
\text { fabrication; properties; applications. } \\
2 x 1.5 \text { hr Lecture }\end{array}$ \\
\hline $\begin{array}{l}\text { Sustainable } \\
\text { Construction }\end{array}$ & $\begin{array}{l}\text { Recycled concrete aggregates; LEED } \\
\text { certification; recycled steel, Efforts in timber } \\
\text { industry } \\
2 x 1.5 \text { hr Lecture }\end{array}$ \\
\hline Resilience & $\begin{array}{l}\text { Extreme events; disaster and risk; functionality; } \\
\text { recovery } \\
2 x 1.5 \text { hr Lecture }\end{array}$ \\
\hline
\end{tabular}




\section{APPENDIX B: Beam Geometry and Reinforcement Details}

Beam A: No Steel Reinforcement

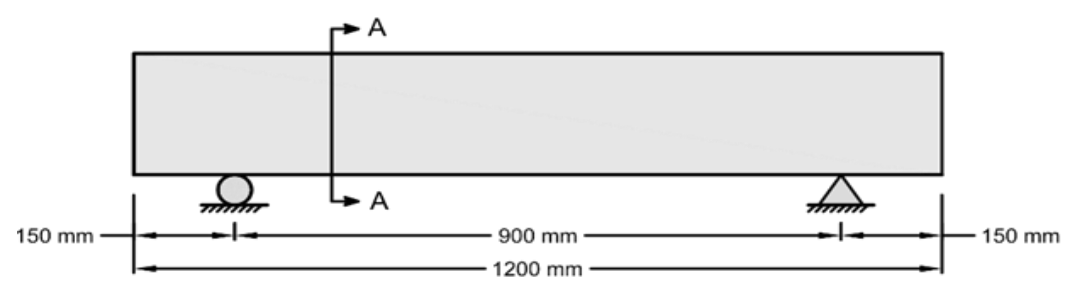

$f_{c}=35 \mathrm{MPa} ;$ Average Failure Load $=65.4 \mathrm{kN}(+/-4 \mathrm{kN})$

Beam B: Flexural Reinforcement

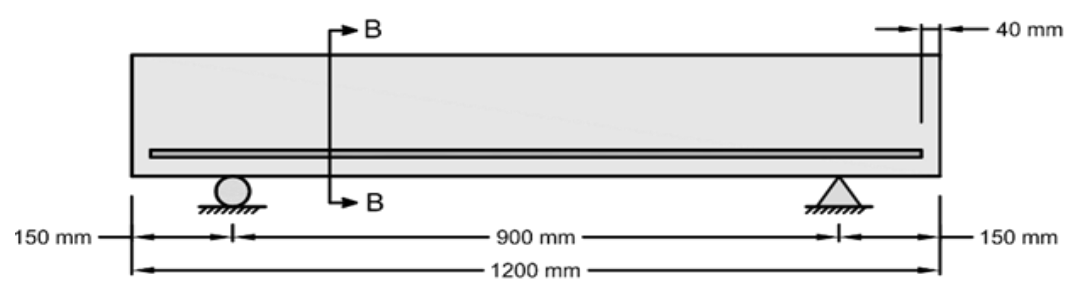

$f_{c}=$ Varies per lab section; $\rho_{1}=0.5 \%$

Average Failure Load $=210.1 \mathrm{kN}(+/-41.3 \mathrm{kN})$

Beam C: Flexural Reinforcement and Shear Reinforcement

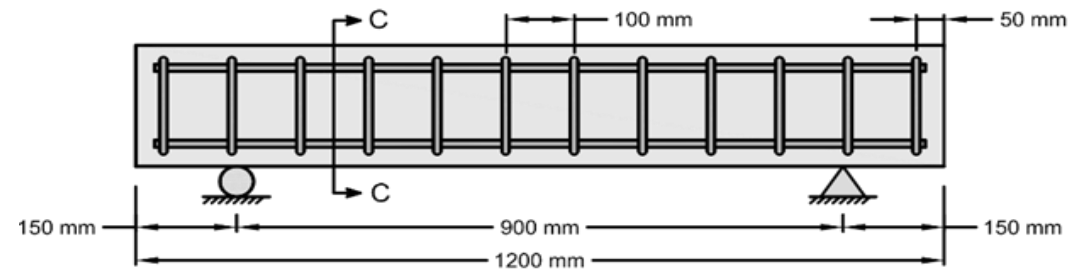

$f_{c}=$ Varies per lab section; $\rho_{1}=0.5 \% ; \rho_{1}^{\prime}=0.33 \% \rho_{t}=0.5 \%$;

Average Failure Load $=286.4 \mathrm{kN}(+/-29.8 \mathrm{kN})$

Beam D: Flexural Reinforcement, Shear Reinforcement, FRP Reinforcement

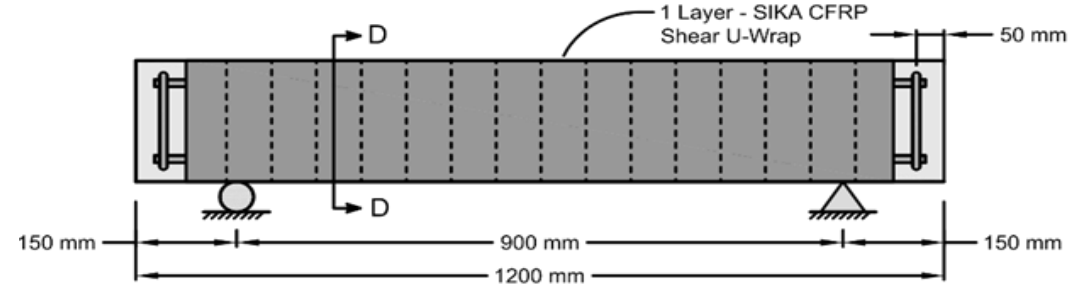

$f_{c}=35 \mathrm{MPa} ; \rho_{1}=0.5 \% ; \rho_{\prime}^{\prime}=0.33 \% \rho_{\mathrm{t}}=0.5 \%$;

Failure Load (One Test) $=319.4 \mathrm{kN}$

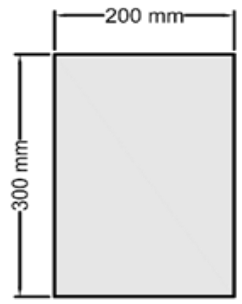

Section A-A

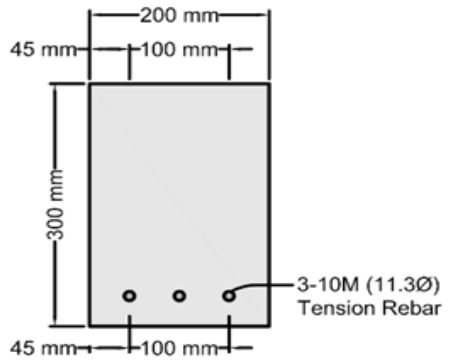

Section B-B

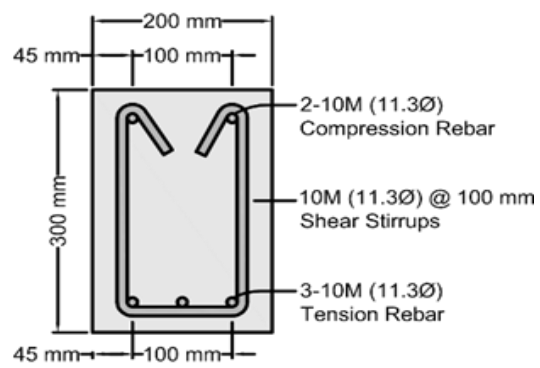

Section C-C

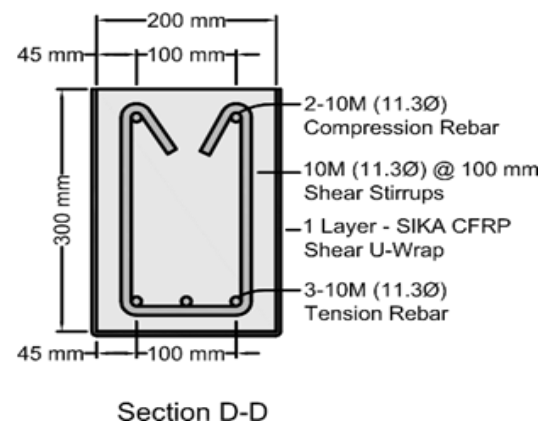

